within a few meters of the glacier bed at center line $(170 \mathrm{~m}$ depth), and debris-laden ice taken from the glacier bed at the lateral margin. Uniaxial compression experiments were conducted on the glacier-ice samples, using the triaxial testing apparatus of the IGB at ETH-Höngerberg. Laboratory studies of ice deformation were carried out under the guidance of A. Hofer, P. Hertzog and Professor Huder of IGB. Sample temperature, volume and strain-rate were monitored throughout each experiment. The confining pressure of each experiment was set at 4 bars (1 bar $=100 \mathrm{kPa})$. The deviatoric stresses applied were 1,2 and 4 bars, and testing temperatures were set at $-1.5,-0.8$ and $-0.4^{\circ} \mathrm{C}$ for each type of ice sampled (clean bubbly, clean clear, and debris-laden).

Preliminary results from experiments conducted on the clean bubbly and clean clear ice indicate that the mechanical behavior of the main bulk of the glacier is well represented by a power-law creep relationship with an exponent of about 4 . This value is in close agreement with independent results obtained from bore-hole-tilt studies (Iken and others, unpublished) and within the range of values cited in the published literature (Paterson 1983). The pre-exponential factor is not well represented by an Arrhenius-type relationship, and enhanced deformation is indicated for samples tested nearest the melting point. Additional laboratory and field studies on the ice-crystal fabrics and the behavior of the debris-laden ice are still in progress. In this paper the results of these investigations are discussed, with special emphasis on information gained from the ice-core drilling studies.

\section{REFERENCES}

Brugman M M, Meier M F 1981 Response of glaciers to the eruptions of Mount St. Helens. U.S. Geological Survey Professional Paper 1250: 743-756

Kamb W B and 7 others 1985 Glacier surge mechanism: 1982-1983 surge of Variegated Glacier, Alaska. Science 227(4686): $469-479$

Paterson W S B 1983 Deformation within polar ice sheets: an analysis of the Byrd Station and Camp Century borehole tilting measurements. Cold Regions Science and Technology 8(2): 165-179

\title{
TRACE ELEMENTS IN SIMULTANEOUSLY SAMPLED AEROSOL AND SNOW FROM THE ANTARCTIC PENINSULA
}

\author{
(Abstract) \\ by \\ Alan L. Dick \\ (British Antarctic Survey, High Cross, Madingley Road, Cambridge CB3 OET, England)
}

*Present address: Chemistry Division, DSIR, Private Bag, Petone, New Zealand

\begin{abstract}
Ultra-clean techniques have been used to collect a series of fresh surface-snow samples on Gipps Ice Rise, Larsen Ice Shelf $\left(68^{\circ} 48^{\prime} \mathrm{S}, 60^{\circ} 54^{\prime} \mathrm{W}\right)$ between 21 December 1984 and 12 February 1985. Aerosol samples were collected simultaneously on to pre-cleaned membrane filters to allow the direct comparison of trace-element levels in air and snow. Samples have been analysed by various techniques for cadmium, copper, lead, zinc, aluminium, calcium, potassium and sodium. For all elements, cross-sample concentration profiles have been obtained to support the data for snow samples.

The heavy-metal concentrations found in the surface snow were similar to those measured previously near Gomez
\end{abstract}

Nunatak in the Antarctic Peninsula. The mean aerosol concentrations found at Gipps Ice Rise were $\mathrm{Cd}$ : $0.06 \mathrm{pg} \mathrm{m}^{-3}, \mathrm{Cu}: 1.0 \mathrm{pg} \mathrm{m}^{-3}, \mathrm{~Pb}: 4.7 \mathrm{pg} \mathrm{m}^{-3}, \mathrm{Zn}: 6.1 \mathrm{pg} \mathrm{m}^{-3}$ These are the lowest concentrations measured so far in Antarctic aerosol.

The ratio of the snow concentration $\left(\mathrm{pg} \mathrm{g}^{-1}\right)$ to air concentration $\left(\mathrm{ng} \mathrm{m}^{-3}\right)$, known as the washout factor, has been calculated for each element and sampling period. The data show that, for the Antarctic Peninsula, the marine aerosol is more efficiently removed to the snow-pack than is the crustal aerosol. Heavy metals are least efficiently removed. This result suggests that the measurement of concentrations in snow and ice alone may lead to misinterpretation of atmospheric source strengths. 